\title{
Beer and Bread to Brains and Beyond: Can Yeast Cells Teach Us about Neurodegenerative Disease?
}

\author{
Aaron D. Gitler \\ Department of Cell and Developmental Biology, University of Pennsylvania School of Medicine, Philadelphia, Pa., \\ USA
}

\section{Key Words}

Yeast $\cdot$ Neurodegeneration $\cdot$ Parkinson's disease $\cdot$

Huntington's disease - Friedreich's ataxia - Niemann-Pick

disease $\cdot$ High-throughput screening

\begin{abstract}
For millennia, humans have harnessed the astonishing power of yeast, producing such culinary masterpieces as bread, beer and wine. Therefore, in this new millennium, is it very farfetched to ask if we can also use yeast to unlock some of the modern day mysteries of human disease? Remarkably, these seemingly simple cells possess most of the same basic cellular machinery as the neurons in the brain. We and others have been using the baker's yeast, Saccharomyces cerevisiae, as a model system to study the mechanisms of devastating neurodegenerative diseases such as Parkinson's, Huntington's, Alzheimer's and amyotrophic lateral sclerosis. While very different in their pathophysiology, they are collectively referred to as protein-misfolding disorders because of the presence of misfolded and aggregated forms of various proteins in the brains of affected individuals. Using yeast genetics and the latest high-throughput screening technologies, we have identified some of the potential causes underpinning these disorders and discovered conserved genes that have proven effective in preventing neuron loss in animal models. Thus, these genes represent new potential drug targets. In this review, I highlight recent work investigating
\end{abstract}

mechanisms of cellular toxicity in a yeast Parkinson's disease model and discuss how similar approaches are being applied to additional neurodegenerative diseases.

Copyright $\odot 2008$ S. Karger AG, Basel

\section{Introduction}

As our population continues to age, neurodegeneration will increase in prevalence and thus pose a daunting challenge to public health worldwide. These truly disastrous neurodegenerative diseases include Alzheimer's, Huntington's, Parkinson's, amyotrophic lateral sclerosis and the frontal temporal dementias [1]. Interestingly, though disparate in their pathophysiology, many of these disorders share a common theme manifest in the accumulation of insoluble protein aggregates in the brain. One of the paramount research goals in the field is the elucidation of mechanisms causing these proteins to misfold and aggregate, as well as to understand their function in normal biology. Protein folding is critically important for all of life, from microbes to man [2]. A bafflingly diverse set of cellular mechanisms has evolved to coordinate this exquisitely sensitive process [3-7]. Since dealing with misfolded proteins is an ancient problem, some of the mechanisms employed to cope with them are likely conserved from yeast to man. Here I illustrate how basic studies in yeast cells can provide a toehold for ex- 
ploring mechanisms of cell death attributed to the aberrant accumulation and/or function of human disease proteins.

\section{Why Use Yeast?}

Baker's yeast, or Saccharomyces cerevisiae, is a versatile experimental system for studying complex biological processes [8-12]. Notably, many of the key cellular pathways of yeast are very similar to those of mammalian cells and strains with gain- or loss-of-function mutations in these pathways are available $[13,14]$. There are many advantages to the yeast system: the yeast genome is very well characterized and amenable to genetic manipulation $[15$, 16]. Methods are available to rapidly overexpress or knock out almost every gene and efforts to generate a collection of strains, each harboring a single mutation [17-19] as well as a collection of expression vectors with each yeast open reading frame [20-23] have recently come to fruition. Another major advantage of the yeast system is the availability of a rich and easily accessible dataset on genetic interactions, protein-protein interactions, transcriptional changes and protein localization [24-31]. Thus, the tools are now available and yeast is poised to be a robust new system for investigating, on a genome-wide scale, the mechanisms underlying many cellular processes, with direct relevance to human disease and for the discovery of novel drug targets for therapeutic intervention [32-37]. While at first it may seem implausible that yeast cells will provide any insight into mechanisms of neurodegenerative disease, it is worth noting that almost everything we know today about cancer biology has, as its foundation, basic studies begun in yeast $[38,39]$.

\section{Parkinson's Disease and $\alpha$-Synuclein}

Parkinson's disease (PD) is the second most common neurodegenerative disorder, exceeded by only Alzheimer's disease [40-47]. Clinical manifestations of PD include severe motor defects characterized by resting muscle tremor ('pill-rolling'), muscle rigidity, bradykinesia and postural instability [48]. PD is characterized by the selective loss of dopaminergic neurons from substantia nigra pars compacta [49]. Accruing evidence points to a causative role for the presynaptic protein $\alpha$-synuclein $(\alpha-$ syn) in the pathogenesis of PD. $\alpha$-Syn is a major constituent of Lewy bodies, cellular inclusions that are the pathological hallmark of PD as well as several other neurode- generative disorders [50-53]. Moreover, several missense mutations in the $\alpha$-syn gene (A53T, A30P, E46K) [54-56] as well as duplication or triplication of the wild-type locus have been shown to cause PD [57-59].

Genetically tractable model organisms have been employed to study the role of $\alpha$-syn in PD [60-62]. Overexpression studies of $\alpha$-syn, or its PD-linked mutants, in mouse, rat, fly and nematode have all converged on the conclusion that increased levels of $\alpha$-syn lead to neurotoxicity [63-68]. But despite intense study of $\alpha$-syn, frustratingly little is known about its normal cellular function and how that function contributes to the disease [69, 70]. Yet it is becoming increasingly clear that, for a number of disease proteins, key to disease may be understanding the normal function of the protein $[71,72]$.

\section{Yeast Model of PD}

Protein misfolding and aggregation can be deleterious to all cell types. Reasoning that $\alpha$-syn accumulation might pose a similar problem to yeast cells as it does to neurons, and that it therefore represents a particularly tractable platform to investigate the cell biology of these defects, Outeiro and Lindquist [34] created a yeast model of $\alpha$-syn cellular toxicity. They began by constructing a yeast strain that expressed $\alpha$-syn fused to the green fluorescent protein (GFP) to allow in vivo visualization of the protein. This fusion protein localized strongly to the plasma membrane (fig. 1a), consistent with the propensity of $\alpha$-syn to interact with phospholipids [73-80]. Remarkably, simply doubling the expression levels of $\alpha$-syn dramatically changed its localization, with the majority of $\alpha$-syn now found in large cytoplasmic inclusions (fig. 1b). Moreover, whereas a single copy of $\alpha$-syn had no significant effect on cell growth, 2 copies resulted in profound cytotoxicity, resulting in growth inhibition and cell death (fig. 1c). Thus, expressing $\alpha$-syn in yeast provided a simple, yet powerful model system for systematically interrogating the cellular consequences of aberrant $\alpha$-syn accumulation [21, 79, 81-85].

\section{A Genome-Wide Screen in Yeast Identifies Modifiers of $\alpha$-syn Toxicity}

We recently carried out a genome-wide screen in yeast to discover suppressors and enhancers of $\alpha$-syn cytotoxicity [21; unpubl. data]. We reasoned that the types of modifier genes identified in our screen would provide in- 
Fig. 1. Expressing $\alpha$-syn in yeast. a A single copy of $\alpha$-syn-GFP is localized to the plasma membrane. $\mathbf{b}$ When a second copy is integrated into the genome, doubling its accumulation, the fate of the protein is profoundly altered; the vast majority of $\alpha$ syn-GFP appears in large cytoplasmic inclusions. c One copy of $\alpha$-syn has little or no effect on growth, while 2 copies show complete growth inhibition.

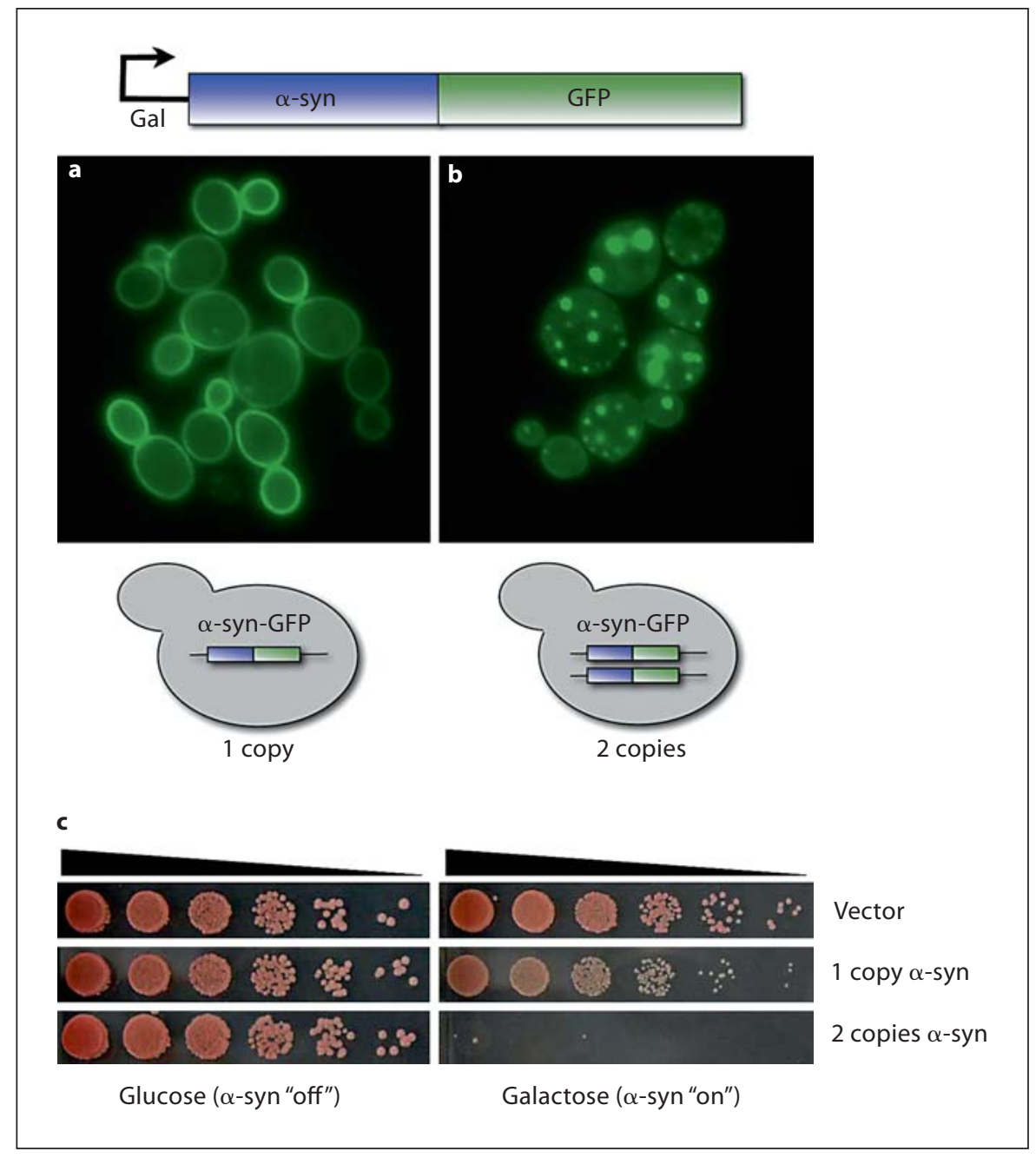

sight into the specific cellular pathways perturbed by $\alpha$ syn accumulation, and ultimately suggest novel avenues for therapeutic investigation. A critical aspect of highthroughput screening is the reliability of the starting library and the harmonization of screening procedures. Accordingly, we participated in efforts to generate what will become the 'gold standard' in yeast genomic libraries. In collaboration with the Harvard Institute of Proteomics (Cambridge, Mass., USA), we helped create an arrayed library of 5,000 completely sequence-verified yeast genes in Gateway ${ }^{\circledR}$ cloning system-based expression vectors $[20,21]$. Unlike existing libraries that contain fragments of genes and/or often mutations that complicate interpretation of results, this library contains only full-length genes and is free of mutations.

Using this library, we performed a high-throughput yeast overexpression screen to identify modifier genes that antagonized cellular toxicity resulting from the ac- cumulation of the PD-linked $\alpha$-syn protein [21; unpubl. data]. As illustrated in figure 2, each of the 5,000 genes was introduced into a yeast strain that also expressed $\alpha$ syn and the ability of each gene to ameliorate or worsen the toxicity was assessed. Intriguingly, many of the yeast genes identified that had effects have clear human orthologues. The largest and most effective class of modifiers was a group of highly conserved genes involved in vesiclemediated transport between the endoplasmic reticulum and Golgi. Moreover, the earliest defects in yeast cells accumulating $\alpha$-syn was impaired endoplasmic reticulumGolgi trafficking [21].

We sought to extend and validate these findings from yeast in neuronal PD models. In collaboration with Drs. Nancy Bonini (University of Pennsylvania; fruit fly PD model), Guy Caldwell (University of Alabama; worm PD model) and Jean-Christophe Rochet (Purdue University; rat embryonic neuron culture model), we tested the abil- 
Fig. 2. Genome-wide $\alpha$-syn toxicity modifier screen. Yeast cells poised to express $\alpha$ syn were transformed individually with each of $\sim 5,000$ expression plasmids, each harboring a unique full-length yeast open reading frame (ORF). Transformants were selected by growth in media lacking uracil and then spotted onto agar plates containing galactose, to induce expression of $\alpha$ syn and the gene of interest. Plates were incubated for 2-3 days and genes that suppressed or enhanced $\alpha$-syn toxicity were identified by those that modified the ability of the yeast to grow: Suppressors allow more robust growth, while enhancers knock down the ability to grow even further than with $\alpha$-syn alone.

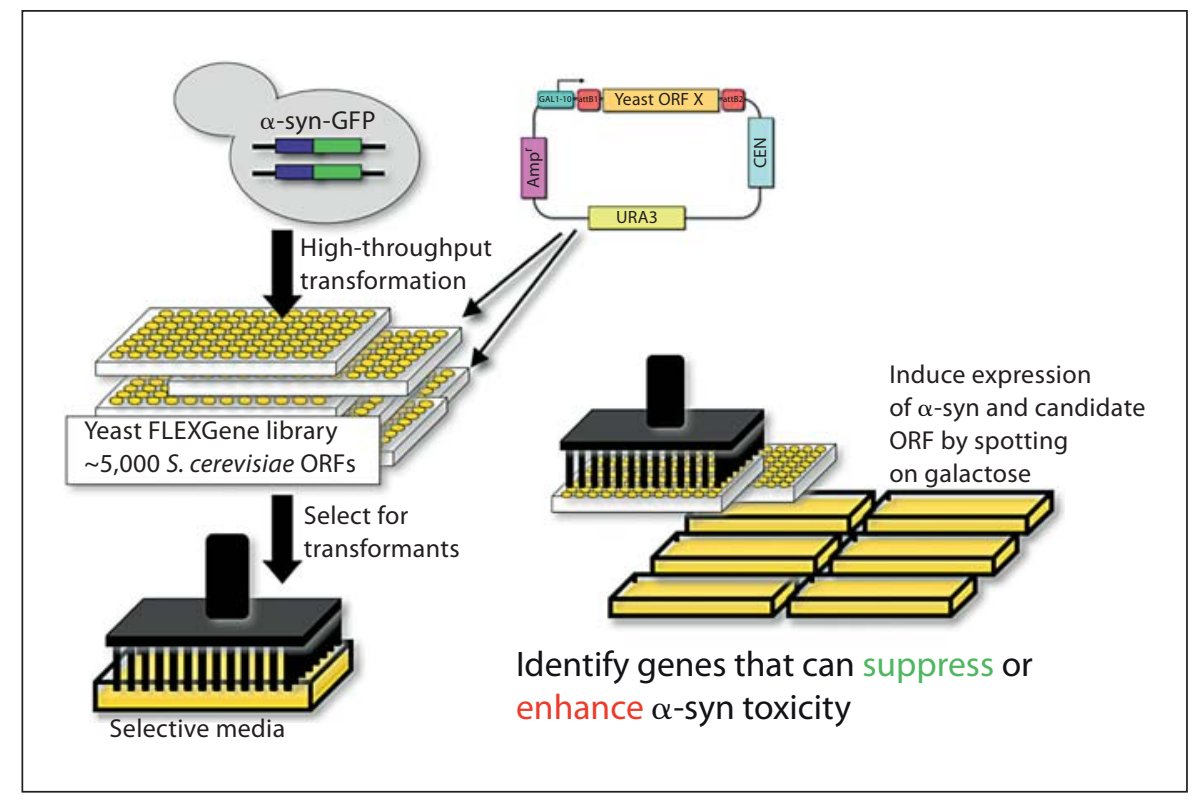

ity of Rab1, the mammalian orthologue of Ypt1p - one of our best yeast $\alpha$-syn toxicity suppressors, to prevent dopaminergic neuron loss. Remarkably, in each model tested Rabl coexpression was sufficient to suppress $\alpha$-syninduced dopaminergic neuron loss. Additional work is required to delineate the mechanisms by which Rab1 antagonizes $\alpha$-syn toxicity; however, these results serve as proof-of-concept that hits uncovered from our yeast screen can have direct relevance to neuronal $\alpha$-syn pathophysiology. Importantly, this paradigm of yeast highthroughput screening followed by validation in animal models of PD is readily amenable to small-molecule drug screens for PD therapeutics.

\section{Rising to the Occasion: Additional Yeast Models of Neurodegenerative Disease}

\section{Huntington's Disease}

Huntington's disease (HD) is an autosomal dominant neurodegenerative disorder characterized by the progressive loss of medium spiny neurons from the striatum and cerebral cortex, causing involuntary movements, speech difficulties, problems with balance and swallowing, depression, mood swings, dementia, and inevitably death $[86,87]$. The HD gene was defined in 1993, and encodes an enormous protein called huntingtin, whose normal function still remains enigmatic [88]. The N-terminal region of huntingtin contains a polyglutamine (polyQ) tract and HD patients harbor pathogenic polyQ expansions [89-91]. Postmortem evaluation reveals cytoplasmic and/or intranuclear inclusions of aggregated fragments of expanded polyQ huntingtin protein in the brains of affected individuals $[87,92]$. Though variable, all healthy individuals have less than 37 glutamines and those with more than 40 are certain to develop HD [93]. Moreover, the greater the size of the polyQ expansion the earlier the age of onset of the disease [89].

Several groups have used yeast to explore the cellular consequences of polyQ expansions [94-97]. Intriguingly, expressing a fragment of huntingtin fused to GFP results in polyQ length-dependent aggregation; fusion proteins containing nonpathogenic Q lengths of 25 or fewer are diffusely distributed throughout the cytosol, whereas Q lengths of 72 and 103 result in the formation of tight fluorescent foci. In certain contexts, expressing these proteins in yeast cells also results in Q length-dependent cytotoxicity [95]. Thus, the yeast model faithfully recapitulates 2 key features of the disease: Q length-dependent aggregation and cytotoxicity. Recent work in yeast has provided insight into the contributions of amino acid sequences flanking the polyQ region within huntingtin that modulate its aggregation and toxicity [98]. No other model system is as amenable to this type of rapid in vivo structure/function analysis as yeast.

Genome-wide screens in yeast have been performed to identify modifiers of huntingtin aggregation and cellular toxicity $[99,100]$. A synthetic lethal screen, in which a partially toxic huntingtin construct was introduced into each of 4,850 nonessential gene deletion strains to iden- 
tify toxicity enhancers, uncovered genes involved in protein folding, response to stress and ubiquitin-mediated protein degradation [100]. Interestingly, a similar screen with PD-linked $\alpha$-syn resulted in a nonoverlapping set of genes, suggesting that the phenotypes in yeast were not merely attributed to nonspecific effects of overexpressing a misfolded foreign protein, but rather were exquisitely specific to the underlying biology of the individual disease protein. A complementary screen was also performed looking for gene deletions that suppressed the toxicity of polyQ huntingtin protein [99]. Undoubtedly, large-scale small molecule screens are underway to identify potential HD therapeutics [101]. As one example, green tea polyphenol (-)-epigallocatechin-3-gallate (EGCG) has already shown promise in ameliorating polyQ toxicity and aggregation in yeast as well as in animal models of HD [102]. The yeast platform will be critical for refining and improving the efficacy of such lead compounds. Finally, it is noteworthy that there are at least 9 inherited neurodegenerative diseases, including $\mathrm{HD}$, caused by polyQ expansions [103]. It is likely that studies in the yeast polyQ model will provide insight into mechanisms of these other related diseases as well.

\section{Friedreich's Ataxia}

Friedreich's ataxia (FRDA) is an autosomal recessive degenerative disorder primarily affecting the nervous system and heart. Clinical features of FRDA include ataxia, sensory loss, muscle weakness and cardiomyopathy [104]. In 1996, the gene responsible for FRDA was cloned and found to encode a relatively small protein, which was termed frataxin [105]. Unfortunately, frataxin's primary amino acid sequence did not shed light on its potential cellular function. But it was noted that there were orthologues present in worm and yeast. By 1997, 2 groups had seized on this observation and generated yeast models of FRDA [106, 107]. The yeast gene YFH1 (yeast frataxin homologue) was originally identified by virtue of its ability to suppress the phenotype of a mutant strain unable to grow on iron-limited medium, suggesting a potential role for frataxin in iron metabolism [106]. Yeast cells lacking YFH1 exhibited profound mitochondrial defects; $y$ fhl $\Delta$ cells are unable to grow on nonfermentable carbon sources (indicating respiratory deficiency) and, in some strain backgrounds, completely lacked mitochondrial DNA [106, 107]. In further support for a role in mitochondrial function, Yfhlp is localized to mitochondria. Remarkably, wild-type human frataxin, but not a patient-derived point mutant, is sufficient to rescue the growth phenotype of $y f h 1 \Delta$ cells. Clinical and pathological overlap between FRDA and mitochondrial diseases had long been appreciated [108], but these groundbreaking studies in yeast provided the first direct link between FRDA, frataxin, iron metabolism and mitochondrial function.

Subsequent studies have indicated a role for frataxin in the assembly and/or maintenance of iron-sulfur clusters, which are prosthetic groups in many mitochondrial proteins, including aconitase and the first 3 respiratory complexes $[109,110]$. The yeast system is well suited to help answer some of the immediate questions that these findings raise: which proteins interact with frataxin/ Yfhlp? Which genes are able to modify the $y$ fh $1 \Delta$ growth phenotype and thus help to further delineate the cellular functions for frataxin/Yfhlp? And perhaps most attractive about this yeast FRDA model will be the ability to perform high-throughput drug screens to identify potential FRDA therapeutics.

\section{Niemann-Pick Disease Type C}

Niemann-Pick disease refers to a collection of lysosomal storage disorders, including types A, B and C. Niemann-Pick disease type C (NP-C) is a fatal autosomal recessive neurodegenerative disease characterized by abnormal accumulation of low-density lipoprotein-derived cholesterol [111]. Though clinically heterogeneous, the most common forms of NP-C begin in the late-infantile and juvenile periods. Clinical manifestations include hepatic, neurologic and psychiatric phenotypes. Later symptoms include movement and speech difficulties $[112,113]$. Positional cloning of the NP-C gene (NPC1) revealed a closely related gene present in yeast (NCR1) [114]. Indeed, expressing the yeast Ncrlp protein in NPC1deficient mammalian cells is sufficient to reverse cholesterol accumulation defects, suggesting a conserved function between the yeast and human proteins [115]. Introducing dominant mutations into Ncrlp results in defects in sphingolipid metabolism, but deleting the yeast NCR1 gene has no effect on cell growth under basal conditions [115]. However, ncrl $\Delta$ cells are not completely normal; they exhibited a dramatic resistance to the antitumor ether-lipid, alkylphosphocholine drug, edelfosine [116]. This effect is completely eliminated when the wild-type $N C R 1$ gene is reintroduced, strongly suggesting that this drug resistance phenotype is attributed to loss of NCR1. Thus, the yeast NP-C model system provides a tractable platform for performing structure/function analysis to determine the effect of specific patient mutations on the $\mathrm{NPC1/Ncrlp}$ protein as well as small-molecule and genetic screens to discover possible treatments for NP-C. 
Fig. 3. Using the yeast models to explore mechanisms of neurodegeneration and for discovering genetic and small molecule modifiers. Each new yeast model of neurodegenerative disease can be integrated into a pipeline of genetic screens (synthetic lethal screen and overexpression screen), transcriptional profiling by microarray, and high-throughput small-molecule screens. Measured readouts can be toxicity, aggregation or other more specialized phenotypes.

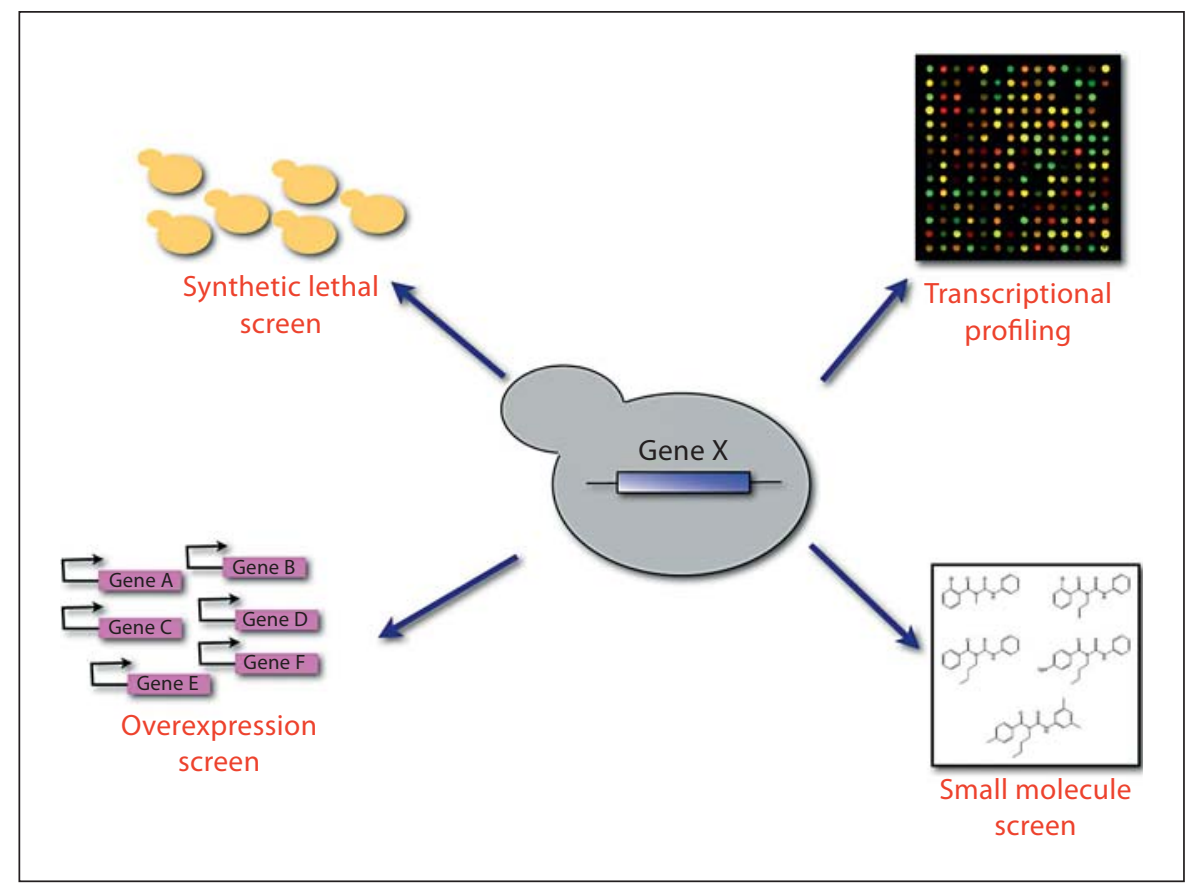

\section{Prion Diseases}

The transmissible spongiform encephalopathies are a collection of fatal neurodegenerative disorders, including bovine spongiform encephalopathy ('mad cow disease') in cattle, scrapie in sheep, as well as Creutzfeldt-Jakob disease, Gerstmann-Sträussler syndrome, kuru, and fatal familial insomnia in people [117-120]. Humans with prion disease present with dementia and, in some cases, cerebellar ataxia. Postmortem pathological examination reveals spongiform degeneration and astrogliosis in the brains of afflicted individuals [121]. Overwhelming evidence implicates the prion protein $\mathrm{PrP}$ as the causative agent in transmissible spongiform encephalopathies [122-124]. PrP exists in 2 conformations, designated $\mathrm{PrP}^{\mathrm{c}}$ (normal form) and $\mathrm{PrP}^{\mathrm{Sc}}$ (disease form). The protein-only prion hypothesis posits $\mathrm{PrP}^{\mathrm{Sc}}$ is itself the infectious agent because it templates the conversion of existing $\operatorname{PrP}^{c}$ to the $\mathrm{PrP}^{\mathrm{Sc}}$ form, thus creating a vicious cycle of infectivity $[125,126]$. Little is known about PrP's cellular function (mouse PrP knockout mice are grossly normal [127, 128]), though emerging evidence suggests it might play a role in stem cell maintenance and neurogenesis $[129,130]$. The yeast system has been used to study the conversion of $\mathrm{PrP}^{\mathrm{c}}$ to $\operatorname{PrP}^{\mathrm{Sc}}$ [131]. Expression of $\operatorname{PrP}$ in the yeast cytoplasm resulted in robust conversion of $\mathrm{PrP}^{\mathrm{c}}$ to a protease-resistant and detergent-insoluble $\mathrm{Prp}^{\mathrm{Sc}}$-like conformation [131]. The yeast system is the perfect venue for performing large-scale genetic and chemical screens to look for modifiers of $\mathrm{PrP}^{\mathrm{c}} \rightarrow \mathrm{PrP}^{\mathrm{Sc}}$ conversion. Yeast has also been used to investigate the normal cellular function of $\operatorname{PrP}$ [132]. When expressed in yeast cells, the mammalian proapoptotic protein Bax causes cell death. Similar to what had been observed in neurons, coexpressing PrP was sufficient to rescue this lethality, providing evidence for a cytoprotective role of PrP. Yeast screens could be used to identify genes and small molecules that modulate $\mathrm{PrP}$ activity.

\section{The Effect of Aging on Yeast Neurodegenerative Disease Models}

Aging is by far the most common risk factor for developing neurodegenerative disease [133]. Strikingly, many of the key aspects of yeast aging closely resemble those of mammalian cells, especially postmitotic neurons (for example oxidative stress, decreased proteasome function and the accumulation of somatic mutations) [134-136]. The biology of postmitotic cells is profoundly different than that of dividing cells and since in almost all of these diseases it is predominantly postmitotic neurons that are affected, examining yeast models of neurodegenerative disease in the context of nondividing aged cells will be crucial, and perhaps much more directly relevant to the biology of aging neurons [137]. 
There are 2 types of aging models in yeast: replicative and chronological $[138,139]$. Replicative aging refers to the number of cell divisions a mother cell will undergo before dying ( $\sim 20$ divisions), whereas chronological aging refers to the ability of yeast cells, when nutrients are depleted, to exit the cell cycle and remain viable in stationary phase for weeks [137]. Yeast cells in stationary phase must cope with the same challenges that the neurons in our brain face over a lifetime: the accumulation of damaged proteins, oxidative stress, proteasome impairment and the buildup of mutations, without the ability to dilute out these cellular insults by dividing. It will be important to test the effect of stationary phase aging on existing as well as future yeast models of neurodegenerative disease [140]. Finally, the expanding repertoire of yeast genomic resources will facilitate high-throughput genetic screens to elucidate key regulators of aging, leading to therapeutic strategies aimed at boosting the ability of neurons to deal with the unrelenting cellular stresses associated with the aging process [141].

\section{Create Your Own Yeast Disease Model}

The above examples illustrate the many different ways yeast cells have been applied to studying neurodegenerative diseases. Yet, this approach is simply the tip of an iceberg, providing the foundation for many additional yeast models for neurodegenerative and other diseases. In some cases, heterologous expression of a wild-type or mutant human protein will be necessary, while in other instances, it may be of interest to mutate the yeast homologue of a human disease gene. Creating fusions to fluorescent proteins (for example GFP and DsRed) or protein tags (for example FLAG, HA and TAP) will enable the visualization of aggregate formation and dynamics as well as the purification of protein complexes containing the disease protein of interest. For protein-misfolding diseases, yeast can be used to monitor the aggregation properties of a disease protein (for example Alzheimer's amyloid $\beta$ peptides) and might bring a fresh perspective to the debate over what truly constitutes the toxic species in many of these disorders [142]. Newly developed yeast models could then be rapidly plugged into a multifaceted regime of genetic and small-molecule screens (fig. 3 ) to discover novel modifiers of aggregation and toxicity as well as to help assign cellular functions to new disease genes.

\section{Acknowledgments}

A.D.G. is supported in part by Pilot Grants from the University of Pennsylvania Institute on Aging, the Alzheimer's Disease Core Center, and a Fellow Award from the McCabe Fund. I am grateful to Dan Kessler, Robert Wilson, Nancy Bonini and Jim Shorter for helpful comments on the manuscript.

\section{References}

1 Forman MS, Trojanowski JQ, Lee VM: Neurodegenerative diseases: a decade of discoveries paves the way for therapeutic breakthroughs. Nat Med 2004;10:1055-1063.

2 Dobson CM: Protein folding and misfolding. Nature 2003;426:884-890.

-3 Singer MA, Lindquist S: Thermotolerance in Saccharomyces cerevisiae: the yin and yang of trehalose. Trends Biotechnol 1998;16: 460-468.

4 Varshavsky A: Regulated protein degradation. Trends Biochem Sci 2005;30:283-286.

5 Weibezahn J, Schlieker C, Tessarz P, Mogk A, Bukau B: Novel insights into the mechanism of chaperone-assisted protein disaggregation. Biol Chem 2005;386:739-744.

-6 Young JC, Agashe VR, Siegers K, Hartl FU: Pathways of chaperone-mediated protein folding in the cytosol. Nat Rev Mol Cell Biol 2004;5:781-791.

7 Shorter J: Hsp104, a potential weapon to combat diverse neurodegenerative disorders. Neurosignals 2008;16:63-74.
8 Fields S, Johnston M: Cell biology: whither model organism research? Science 2005;307: 1885-1886.

9 Botstein D, Chervitz SA, Cherry JM: Yeast as a model organism. Science 1997;277:12591260.

10 Botstein D, Fink GR: Yeast: an experimental organism for modern biology. Science 1988; 240:1439-1443.

11 Dolinski K, Botstein D: Changing perspectives in yeast research nearly a decade after the genome sequence. Genome Res 2005;15: 1611-1619.

12 Johansson BE, Brett IC: Changing perspective on immunization against influenza. Vaccine 2007;25:3062-3065.

13 Steinmetz LM, Scharfe C, Deutschbauer AM, Mokranjac D, Herman ZS, Jones T, Chu AM, Giaever G, Prokisch H, Oefner PJ, Davis RW: Systematic screen for human disease genes in yeast. Nat Genet 2002;31:400-404.

14 Foury F: Human genetic diseases: a cross-talk between man and yeast. Gene 1997;195:1-10.
15 Goffeau A, Barrell BG, Bussey H, Davis RW, Dujon B, Feldmann H, Galibert F, Hoheisel JD, Jacq C, Johnston M, Louis EJ, Mewes HW, Murakami Y, Philippsen P, Tettelin H, Oliver SG: Life with 6,000 genes. Science 1996;274:546, 563-547.

16 Boone C, Bussey H, Andrews BJ: Exploring genetic interactions and networks with yeast. Nat Rev 2007;8:437-449.

17 Winzeler EA, Shoemaker DD, Astromoff A, Liang H, Anderson K, Andre B, Bangham R, Benito R, Boeke JD, Bussey H, Chu AM, Connelly C, Davis K, Dietrich F, Dow SW, El Bakkoury M, Foury F, Friend SH, Gentalen E, Giaever G, Hegemann JH, Jones T, Laub M, Liao H, Davis RW, et al: Functional characterization of the $S$. cerevisiae genome by gene deletion and parallel analysis. Science 1999;285:901-906. 
18 Giaever G, Chu AM, Ni L, Connelly C, Riles L, Veronneau S, Dow S, Lucau-Danila A, Anderson K, Andre B, Arkin AP, Astromoff A, El-Bakkoury M, Bangham R, Benito R, Brachat S, Campanaro S, Curtiss M, Davis K, Deutschbauer A, Entian KD, Flaherty $\mathrm{P}$, Foury F, Garfinkel DJ, Gerstein M, Gotte D, Guldener U, Hegemann JH, Hempel S, Herman Z, Jaramillo DF, Kelly DE, Kelly SL, Kotter P, LaBonte D, Lamb DC, Lan N, Liang H, Liao H, Liu L, Luo C, Lussier M, Mao R, Menard P, Ooi SL, Revuelta JL, Roberts CJ, Rose M, Ross-Macdonald P, Scherens B, Schimmack G, Shafer B, Shoemaker DD, Sookhai-Mahadeo S, Storms RK, Strathern JN, Valle G, Voet M, Volckaert G, Wang CY, Ward TR, Wilhelmy J, Winzeler EA, Yang Y, Yen G, Youngman E, Yu K, Bussey H, Boeke JD, Snyder M, Philippsen P, Davis RW, Johnston M: Functional profiling of the saccharomyces cerevisiae genome. Nature 2002;418: 387-391.

-19 Mnaimneh S, Davierwala AP, Haynes J, Moffat J, Peng WT, Zhang W, Yang X, Pootoolal J, Chua G, Lopez A, Trochesset M, Morse D, Krogan NJ, Hiley SL, Li Z, Morris Q, Grigull J, Mitsakakis N, Roberts CJ, Greenblatt JF, Boone C, Kaiser CA, Andrews BJ, Hughes TR: Exploration of essential gene functions via titratable promoter alleles. Cell 2004;118: 31-44.

-20 Hu Y, Rolfs A, Bhullar B, Murthy TV, Zhu C, Berger MF, Camargo AA, Kelley F, McCarron S, Jepson D, Richardson A, Raphael J, Moreira D, Taycher E, Zuo D, Mohr S, Kane MF, Williamson J, Simpson A, Bulyk ML, Harlow E, Marsischky G, Kolodner RD, LaBaer J: Approaching a complete repository of sequence-verified protein-encoding clones for Saccharomyces cerevisiae. Genome Res 2007; 17:536-543.

-21 Cooper AA, Gitler AD, Cashikar A, Haynes CM, Hill KJ, Bhullar B, Liu K, Xu K, Strathearn KE, Liu F, Cao S, Caldwell KA, Caldwell GA, Marsischky G, Kolodner RD, Labaer J, Rochet JC, Bonini NM, Lindquist S: $\alpha$-Synuclein blocks ER-golgi traffic and Rab1 rescues neuron loss in Parkinson's models. Science 2006;313:324-328.

$\checkmark 22$ Gelperin DM, White MA, Wilkinson ML, Kon Y, Kung LA, Wise KJ, Lopez-Hoyo N, Jiang L, Piccirillo S, Yu H, Gerstein M, Dumont ME, Phizicky EM, Snyder M, Grayhack EJ: Biochemical and genetic analysis of the yeast proteome with a movable ORF collection. Genes Dev 2005;19:2816-2826.

23 Alberti S, Gitler AD, Lindquist S: A suite of Gateway ${ }^{\circledR}$ cloning vectors for high-throughput genetic analysis in Saccharomyces cerevisiae. Yeast 2007;24:913-919.

-24 Tong AH, Evangelista M, Parsons AB, Xu H, Bader GD, Page N, Robinson M, Raghibizadeh S, Hogue CW, Bussey H, Andrews B, Tyers $\mathrm{M}$, Boone C: Systematic genetic analysis with ordered arrays of yeast deletion mutants. Science 2001;294:2364-2368.
25 Tong AH, Lesage G, Bader GD, Ding H, Xu $\mathrm{H}$, Xin X, Young J, Berriz GF, Brost RL, Chang M, Chen Y, Cheng X, Chua G, Friesen H, Goldberg DS, Haynes J, Humphries C, He G, Hussein S, Ke L, Krogan N, Li Z, Levinson JN, Lu H, Menard P, Munyana C, Parsons AB, Ryan O, Tonikian R, Roberts T, Sdicu AM, Shapiro J, Sheikh B, Suter B, Wong SL, Zhang LV, Zhu H, Burd CG, Munro S, Sander C, Rine J, Greenblatt J, Peter M, Bretscher A, Bell G, Roth FP, Brown GW, Andrews B, Bussey $\mathrm{H}$, Boone C: Global mapping of the yeast genetic interaction network. Science 2004;303:808-813.

26 Ghaemmaghami S, Huh WK, Bower K, Howson RW, Belle A, Dephoure N, O'Shea EK, Weissman JS: Global analysis of protein expression in yeast. Nature 2003;425:737741.

-27 Huh WK, Falvo JV, Gerke LC, Carroll AS, Howson RW, Weissman JS, O'Shea EK: Global analysis of protein localization in budding yeast. Nature 2003;425:686-691.

28 Krogan NJ, Cagney G, Yu H, Zhong G, Guo X, Ignatchenko A, Li J, Pu S, Datta N, Tikuisis AP, Punna T, Peregrin-Alvarez JM, Shales M, Zhang X, Davey M, Robinson MD, Paccanaro A, Bray JE, Sheung A, Beattie B, Richards DP, Canadien V, Lalev A, Mena F, Wong $\mathrm{P}$, Starostine A, Canete MM, Vlasblom J, Wu S, Orsi C, Collins SR, Chandran S, Haw R, Rilstone JJ, Gandi K, Thompson NJ, Musso G, St Onge P, Ghanny S, Lam MH, Butland G, Altaf-Ul AM, Kanaya S, Shilatifard A, O'Shea E, Weissman JS, Ingles CJ, Hughes TR, Parkinson J, Gerstein M, Wodak SJ, Emili A, Greenblatt JF: Global landscape of protein complexes in the yeast Saccharomyces cerevisiae. Nature 2006;440:637-643.

29 Schuldiner M, Collins SR, Thompson NJ, Denic V, Bhamidipati A, Punna T, Ihmels J, Andrews B, Boone C, Greenblatt JF, Weissman JS, Krogan NJ: Exploration of the function and organization of the yeast early secretory pathway through an epistatic miniarray profile. Cell 2005;123:507-519.

30 Chu S, DeRisi J, Eisen M, Mulholland J, Botstein D, Brown PO, Herskowitz I: The transcriptional program of sporulation in budding yeast. Science 1998;282:699-705.

31 Harbison CT, Gordon DB, Lee TI, Rinaldi NJ, Macisaac KD, Danford TW, Hannett NM, Tagne JB, Reynolds DB, Yoo J, Jennings EG, Zeitlinger J, Pokholok DK, Kellis M, Rolfe PA, Takusagawa KT, Lander ES, Gifford DK, Fraenkel E, Young RA: Transcriptional regulatory code of a eukaryotic genome. Nature 2004;431:99-104.

32 Giorgini F, Muchowski PJ: Screening for genetic modifiers of amyloid toxicity in yeast. Methods Enzymol 2006;412:201-222.

33 Hughes T, Andrews B, Boone C: Old drugs, new tricks: using genetically sensitized yeast to reveal drug targets. Cell 2004;116:5-7.
34 Outeiro TF, Lindquist S: Yeast cells provide insight into $\alpha$-synuclein biology and pathobiology. Science 2003;302:1772-1775.

35 Outeiro TF, Muchowski PJ: Molecular genetics approaches in yeast to study amyloid diseases. J Mol Neurosci 2004;23:49-60.

36 Sturgeon CM, Kemmer D, Anderson HJ, Roberge $\mathrm{M}$ : Yeast as a tool to uncover the cellular targets of drugs. Biotechnol J 2006;1: 289-298.

37 Bach S, Talarek N, Andrieu T, Vierfond JM, Mettey Y, Galons H, Dormont D, Meijer L, Cullin C, Blondel M: Isolation of drugs active against mammalian prions using a yeastbased screening assay. Nat Biotechnol 2003; 21:1075-1081.

38 Hartwell LH: Nobel lecture. Yeast and cancer. Biosci Rep 2002;22:373-394.

39 Nurse P: The Nobel Prize and beyond: an interview with Sir Paul Nurse. Interview by Susan R. Owens. EMBO Rep 2002;3:204-206.

40 Forman MS, Lee VM, Trojanowski JQ: Nosology of Parkinson's disease: looking for the way out of a quagmire. Neuron 2005;47:479482 .

41 Forno LS: Neuropathology of Parkinson's disease. J Neuropathol Exp Neurol 1996;55: 259-272.

42 Gasser T: Genetics of Parkinson's disease. J Neurol 2001;248:833-840.

43 Lynch T, Farrer M, Hutton M, Hardy J: Genetics of Parkinson's disease. Science 1997; 278:1212-1213.

44 Moore DJ, West AB, Dawson VL, Dawson TM: Molecular pathophysiology of Parkinson's disease. Annu Rev Neurosci 2005;28: 57-87.

45 Nussbaum RL, Polymeropoulos MH: Genetics of Parkinson's disease. Hum Mol Genet 1997;6:1687-1691.

46 Vila M, Przedborski S: Genetic clues to the pathogenesis of Parkinson's disease. Nat Med 2004;10(suppl):S58-S62.

47 Dawson TM, Dawson VL: Molecular pathways of neurodegeneration in Parkinson's disease. Science 2003;302:819-822.

48 Goedert M: $\alpha$-Synuclein and neurodegenerative diseases. Nat Rev Neurosci 2001;2:492501.

49 Irizarry MC, Growdon W, Gomez-Isla T, Newell K, George JM, Clayton DF, Hyman BT: Nigral and cortical Lewy bodies and dystrophic nigral neurites in Parkinson's disease and cortical Lewy body disease contain $\alpha$-synuclein immunoreactivity. J Neuropathol Exp Neurol 1998;57:334-337.

50 Spillantini MG, Crowther RA, Jakes R, Hasegawa M, Goedert M: $\alpha$-Synuclein in filamentous inclusions of Lewy bodies from Parkinson's disease and dementia with Lewy bodies. Proc Natl Acad Sci USA 1998;95: 6469-6473. 
-51 Spillantini MG, Crowther RA, Jakes R, 63 Auluck PK, Chan HY, Trojanowski JQ, Lee Cairns NJ, Lantos PL, Goedert M: Filamentous $\alpha$-synuclein inclusions link multiple system atrophy with Parkinson's disease and dementia with Lewy bodies. Neurosci Lett 1998;251:205-208.

52 Lee VM, Trojanowski JQ: Mechanisms of Parkinson's disease linked to pathological $\alpha$ synuclein: new targets for drug discovery. Neuron 2006;52:33-38.

53 Baba M, Nakajo S, Tu PH, Tomita T, Nakaya K, Lee VM, Trojanowski JQ, Iwatsubo T: Aggregation of $\alpha$-synuclein in Lewy bodies of sporadic Parkinson's disease and dementia with Lewy bodies. Am J Pathol 1998;152: 879-884.

54 Polymeropoulos MH, Lavedan C, Leroy E, Ide SE, Dehejia A, Dutra A, Pike B, Root H, Rubenstein J, Boyer R, Stenroos ES, Chandrasekharappa S, Athanassiadou A, Papapetropoulos T, Johnson WG, Lazzarini AM, Duvoisin RC, Di Iorio G, Golbe LI, Nussbaum RL: Mutation in the $\alpha$-synuclein gene identified in families with Parkinson's disease. Science 1997;276:2045-2047.

55 Kruger R, Kuhn W, Muller T, Woitalla D, Graeber M, Kosel S, Przuntek H, Epplen JT, Schols L, Riess O: Ala30Pro mutation in the gene encoding $\alpha$-synuclein in Parkinson's disease. Nat Genet 1998;18:106-108.

-56 Zarranz JJ, Alegre J, Gomez-Esteban JC, Lezcano E, Ros R, Ampuero I, Vidal L, Hoenicka J, Rodriguez O, Atares B, Llorens V, Tortosa EG, Del Ser T, Munoz DG, De Yebenes JG: The new mutation, e46k, of $\alpha$ synuclein causes parkinson and Lewy body dementia. Ann Neurol 2004;55:164-173.

-57 Singleton AB, Farrer M, Johnson J, Singleton A, Hague S, Kachergus J, Hulihan M, Peuralinna T, Dutra A, Nussbaum R, Lincoln S, Crawley A, Hanson M, Maraganore D, Adler C, Cookson MR, Muenter M, Baptista M, Miller D, Blancato J, Hardy J, Gwinn-Hardy $\mathrm{K}: \alpha$-Synuclein locus triplication causes Parkinson's disease. Science 2003;302:841.

58 Chartier-Harlin MC, Kachergus J, Roumier C, Mouroux V, Douay X, Lincoln S, Levecque C, Larvor L, Andrieux J, Hulihan M, Waucquier N, Defebvre L, Amouyel P, Farrer M, Destee A: $\alpha$-Synuclein locus duplication as a cause of familial Parkinson's disease. Lancet 2004;364:1167-1169.

59 Ibanez P, Bonnet AM, Debarges B, Lohmann E, Tison F, Pollak P, Agid Y, Durr A, Brice A: Causal relation between $\alpha$-synuclein gene duplication and familial Parkinson's disease. Lancet 2004;364:1169-1171.

60 Dauer W, Przedborski S: Parkinson's disease: mechanisms and models. Neuron 2003; 39:889-909.

-61 Dawson TM: New animal models for Parkinson's disease. Cell 2000;101:115-118.

62 Maries E, Dass B, Collier TJ, Kordower JH, Steece-Collier K: The role of $\alpha$-synuclein in Parkinson's disease: insights from animal models. Nat Rev Neurosci 2003;4:727-738. VM, Bonini NM: Chaperone suppression of $\alpha$-synuclein toxicity in a drosophila model for Parkinson's disease. Science 2002;295: 865-868.

64 Feany MB, Bender WW: A drosophila model of Parkinson's disease. Nature 2000;404: 394-398.

65 Lo Bianco C, Ridet JL, Schneider BL, Deglon N, Aebischer P: $\alpha$-Synucleinopathy and selective dopaminergic neuron loss in a rat lentiviral-based model of Parkinson's disease. Proc Natl Acad Sci USA 2002;99:1081310818.

66 Masliah E, Rockenstein E, Veinbergs I, Mallory M, Hashimoto M, Takeda A, Sagara Y Sisk A, Mucke L: Dopaminergic loss and inclusion body formation in $\alpha$-synuclein mice: implications for neurodegenerative disorders. Science 2000;287:1265-1269.

67 Cao S, Gelwix CC, Caldwell KA, Caldwell GA: Torsin-mediated protection from cellular stress in the dopaminergic neurons of Caenorhabditis elegans. J Neurosci 2005;25: 3801-3812.

68 Lakso M, Vartiainen S, Moilanen AM, Sirvio J, Thomas JH, Nass R, Blakely RD, Wong G: Dopaminergic neuronal loss and motor deficits in Caenorhabditis elegans overexpress ing human $\alpha$-synuclein. J Neurochem 2003; 86:165-172.

69 Bonini NM, Giasson BI: Snaring the function of $\alpha$-synuclein. Cell 2005;123:359-361.

70 Gitler AD, Shorter J: Prime time for $\alpha$-synuclein. J Neurosci 2007;27:2433-2434.

71 Lam YC, Bowman AB, Jafar-Nejad P, Lim J, Richman R, Fryer JD, Hyun ED, Duvick LA, Orr HT, Botas J, Zoghbi HY: ATAXIN-1 interacts with the repressor capicua in its native complex to cause SCA1 neuropathology. Cell 2006;127:1335-1347.

72 Liu N, Bonini NM: Hosting neurotoxicity in polyglutamine disease. Cell 2006;127:12991300.

73 Davidson WS, Jonas A, Clayton DF, George JM: Stabilization of $\alpha$-synuclein secondary structure upon binding to synthetic membranes. J Biol Chem 1998;273:9443-9449.

74 Jo E, Fuller N, Rand RP, St George-Hyslop P, Fraser PE: Defective membrane interactions of familial Parkinson's disease mutant a30p $\alpha$-synuclein. J Mol Biol 2002;315:799-807.

75 Jo E, McLaurin J, Yip CM, St George-Hyslop P, Fraser PE: $\alpha$-Synuclein membrane interactions and lipid specificity. J Biol Chem 2000; 275:34328-34334

76 Kubo S, Nemani VM, Chalkley RJ, Anthony MD, Hattori N, Mizuno Y, Edwards RH, Fortin DL: A combinatorial code for the interaction of $\alpha$-synuclein with membranes. J Biol Chem 2005;280:31664-31672.

$\checkmark 77$ McLean PJ, Kawamata H, Ribich S, Hyman BT: Membrane association and protein conformation of $\alpha$-synuclein in intact neurons: effect of Parkinson's disease-linked mutations. J Biol Chem 2000;275:8812-8816.
78 Perrin RJ, Woods WS, Clayton DF, George JM: Interaction of human $\alpha$-synuclein and Parkinson's disease variants with phospholipids: structural analysis using site-directed mutagenesis. J Biol Chem 2000;275:3439334398.

79 Rochet JC, Outeiro TF, Conway KA, Ding TT, Volles MJ, Lashuel HA, Bieganski RM, Lindquist SL, Lansbury PT: Interactions among $\alpha$-synuclein, dopamine, and biomembranes: some clues for understanding neurodegeneration in parkinson's disease. J Mol Neurosci 2004;23:23-34.

$>80$ Volles MJ, Lee SJ, Rochet JC, Shtilerman MD, Ding TT, Kessler JC, Lansbury PT Jr: Vesicle permeabilization by protofibrillar $\alpha$-synuclein: Implications for the pathogenesis and treatment of Parkinson's disease. Biochemistry 2001;40:7812-7819.

-81 Flower TR, Clark-Dixon C, Metoyer C, Yang H, Shi R, Zhang Z, Witt SN: YGR198w (YPP1) targets A30P $\alpha$-synuclein to the vacuole for degradation. J Cell Biol 2007;177: 1091-1104.

$>82$ Witt SN, Flower TR: $\alpha$-Synuclein, oxidative stress and apoptosis from the perspective of a yeast model of Parkinson's disease. FEMS Yeast Res 2006;6:1107-1116.

$>83$ Flower TR, Chesnokova LS, Froelich CA, Dixon C, Witt SN: Heat shock prevents $\alpha$ synuclein-induced apoptosis in a yeast model of Parkinson's disease. J Mol Biol 2005;351: 1081-1100.

84 Dixon C, Mathias N, Zweig RM, Davis DA, Gross DS: $\alpha$-Synuclein targets the plasma membrane via the secretory pathway and induces toxicity in yeast. Genetics 2005; 170: 47-59.

$>85$ Volles MJ, Lansbury PT Jr: Relationships between the sequence of $\alpha$-synuclein and its membrane affinity, fibrillization propensity, and yeast toxicity. J Mol Biol 2007;366:15101522 .

-86 Ho LW, Carmichael J, Swartz J, Wyttenbach A, Rankin J, Rubinsztein DC: The molecular biology of Huntington's disease. Psychol Med 2001;31:3-14.

87 DiFiglia M: Clinical genetics. II. Huntington's disease: from the gene to pathophysiology. Am J Psychiatry 1997;154:1046.

$>88$ A novel gene containing a trinucleotide repeat that is expanded and unstable on Huntington's disease chromosomes. The Huntington's Disease Collaborative Research Group. Cell 1993;72:971-983.

-89 Andrew SE, Goldberg YP, Kremer B, Telenius $H$, Theilmann J, Adam S, Starr E, Squitieri F, Lin B, Kalchman MA, et al: The relationship between trinucleotide (CAG) repeat length and clinical features of Huntington's disease. Nat Genet 1993;4:398-403.

90 Bates GP, Mangiarini L, Wanker EE, Davies SW: Polyglutamine expansion and Huntington's disease. Biochem Soc Trans 1998;26: 471-475. 
91 Ross CA: Polyglutamine pathogenesis: emergence of unifying mechanisms for Huntington's disease and related disorders. Neuron 2002;35:819-822.

$\checkmark 92$ Becher MW, Kotzuk JA, Sharp AH, Davies SW, Bates GP, Price DL, Ross CA: Intranuclear neuronal inclusions in huntington's disease and dentatorubral and pallidoluysian atrophy: correlation between the density of inclusions and IT15 CAG triplet repeat length. Neurobiol Dis 1998;4:387397.

-93 Rubinsztein DC, Leggo J, Coles R, Almqvist E, Biancalana V, Cassiman JJ, Chotai K, Connarty M, Crauford D, Curtis A, Curtis D, Davidson MJ, Differ AM, Dode C, Dodge A, Frontali M, Ranen NG, Stine OC, Sherr M, Abbott MH, Franz ML, Graham CA, Harper PS, Hedreen JC, Hayden MR, et al: Phenotypic characterization of individuals with 30-40 CAG repeats in the Huntington disease (HD) gene reveals HD cases with 36 repeats and apparently normal elderly individuals with 36-39 repeats. Am J Hum Genet 1996;59:16-22.

$\$ 94$ Krobitsch S, Lindquist S: Aggregation of huntingtin in yeast varies with the length of the polyglutamine expansion and the expression of chaperone proteins. Proc Natl Acad Sci USA 2000;97:1589-1594.

$\checkmark 95$ Meriin AB, Zhang X, He X, Newnam GP, Chernoff YO, Sherman MY: Huntington toxicity in yeast model depends on polyglutamine aggregation mediated by a prion-like protein Rnq1. J Cell Biol 2002;157: 997-1004.

-96 Muchowski PJ, Schaffar G, Sittler A, Wanker EE, Hayer-Hartl MK, Hartl FU: Hsp70 and hsp40 chaperones can inhibit self-assembly of polyglutamine proteins into amyloid-like fibrils. Proc Natl Acad Sci USA 2000;97:7841-7846.

$\checkmark 97$ Hughes RE, Lo RS, Davis C, Strand AD, Neal CL, Olson JM, Fields S: Altered transcription in yeast expressing expanded polyglutamine. Proc Natl Acad Sci USA 2001;98:13201-13206.

98 Duennwald ML, Jagadish S, Muchowski PJ, Lindquist S: Flanking sequences profoundly alter polyglutamine toxicity in yeast. Proc Natl Acad Sci USA 2006;103: 11045-11050.

99 Giorgini F, Guidetti P, Nguyen Q, Bennett SC, Muchowski PJ: A genomic screen in yeast implicates kynurenine 3-monooxygenase as a therapeutic target for Huntington disease. Nat Genet 2005;37:526-531.

100 Willingham S, Outeiro TF, DeVit MJ, Lindquist SL, Muchowski PJ: Yeast genes that enhance the toxicity of a mutant huntingtin fragment or $\alpha$-synuclein. Science 2003;302:1769-1772.

101 Steffan JS, Thompson LM: Targeting aggregation in the development of therapeutics for the treatment of Huntington's disease and other polyglutamine repeat diseases. Expert Opin Ther Targets 2003;7:201-213.
102 Ehrnhoefer DE, Duennwald M, Markovic P, Wacker JL, Engemann S, Roark M, Legleiter J, Marsh JL, Thompson LM, Lindquist S, Muchowski PJ, Wanker EE: Green tea (-)-epigallocatechin-gallate modulates early events in huntingtin misfolding and reduces toxicity in Huntington's disease models. Hum Mol Genet 2006; 15:2743-2751.

103 Taylor JP, Hardy J, Fischbeck KH: Toxic proteins in neurodegenerative disease. Science 2002;296:1991-1995.

104 Durr A, Cossee M, Agid Y, Campuzano V, Mignard C, Penet C, Mandel JL, Brice A, Koenig M: Clinical and genetic abnormalities in patients with Friedreich's ataxia. N Engl J Med 1996;335:1169-1175.

105 Campuzano V, Montermini L, Molto MD, Pianese L, Cossee M, Cavalcanti F, Monros E, Rodius F, Duclos F, Monticelli A, et al: Friedreich's ataxia: autosomal recessive disease caused by an intronic GAA triplet repeat expansion. Science 1996;271:14231427.

106 Babcock M, de Silva D, Oaks R, Davis-Kaplan S, Jiralerspong S, Montermini L, Pandolfo M, Kaplan J: Regulation of mitochondrial iron accumulation by Yfh1p, a putative homolog of frataxin. Science 1997;276: 1709-1712.

107 Wilson RB, Roof DM: Respiratory deficiency due to loss of mitochondrial DNA in yeast lacking the frataxin homologue. Nat Genet 1997;16:352-357.

108 Barbeau A: Friedreich's ataxia 1980: an overview of the physiopathology. Can J Neurol Sci 1980;7:455-468.

109 Bulteau AL, O’Neill HA, Kennedy MC, Ikeda-Saito M, Isaya G, Szweda LI: Frataxin acts as an iron chaperone protein to modulate mitochondrial aconitase activity. Science 2004;305:242-245.

110 Muhlenhoff U, Richhardt N, Ristow M, Kispal G, Lill R: The yeast frataxin homolog Yfhlp plays a specific role in the maturation of cellular $\mathrm{Fe} / \mathrm{S}$ proteins. Hum $\mathrm{Mol}$ Genet 2002;11:2025-2036.

11 Morris JA, Carstea ED: Niemann-Pick C disease: cholesterol handling gone awry. Mol Med Today 1998;4:525-531.

-112 Vanier MT, Wenger DA, Comly ME, Rousson R, Brady RO, Pentchev PG: NiemannPick disease group $\mathrm{C}$ : clinical variability and diagnosis based on defective cholesterol esterification. A collaborative study on 70 patients. Clin Genet 1988;33:331-348.

113 Vanier MT, Millat G: Niemann-Pick disease type C. Clin Genet 2003;64:269-281.

114 Carstea ED, Morris JA, Coleman KG, Loftus SK, Zhang D, Cummings C, Gu J, Rosenfeld MA, Pavan WJ, Krizman DB, Nagle J, Polymeropoulos MH, Sturley SL, Ioannou YA, Higgins ME, Comly $\mathrm{M}$, Cooney A, Brown A, Kaneski CR, Blanchette-Mackie EJ, Dwyer NK, Neufeld EB, Chang TY, Liscum L, Strauss JF, 3rd, Ohno K, Zeigler M, Carmi R, Sokol J, Markie D,
O’Neill RR, van Diggelen OP, Elleder M, Patterson MC, Brady RO, Vanier MT, Pentchev PG, Tagle DA: Niemann-Pick C1 disease gene: homology to mediators of cholesterol homeostasis. Science 1997;277: 228-231.

115 Malathi K, Higaki K, Tinkelenberg AH, Balderes DA, Almanzar-Paramio D, Wilcox LJ, Erdeniz N, Redican F, Padamsee M, Liu Y, Khan S, Alcantara F, Carstea ED, Morris JA, Sturley SL: Mutagenesis of the putative sterol-sensing domain of yeast Niemann Pick C-related protein reveals a primordial role in subcellular sphingolipid distribution. J Cell Biol 2004;164:547-556.

116 Berger AC, Hanson PK, Wylie Nichols J, Corbett AH: A yeast model system for functional analysis of the Niemann-Pick type C protein 1 homolog, Ncrlp. Traffic 2005;6: 907-917.

117 Aguzzi A, Heikenwalder M, Miele G: Progress and problems in the biology, diagnostics, and therapeutics of prion diseases. J Clin Invest 2004;114:153-160.

118 Aguzzi A, Polymenidou M: Mammalian prion biology: one century of evolving concepts. Cell 2004;116:313-327.

119 Prusiner SB: Molecular biology and pathogenesis of prion diseases. Trends Biochem Sci 1996;21:482-487.

120 Prusiner SB, Scott MR, DeArmond SJ, Cohen FE: Prion protein biology. Cell 1998;93: 337-348.

121 Prusiner SB: Prion diseases and the BSE crisis. Science 1997;278:245-251.

122 Bolton DC, McKinley MP, Prusiner SB: Identification of a protein that purifies with the scrapie prion. Science 1982;218:13091311

123 Prusiner SB: Prions. Proc Natl Acad Sci USA 1998;95:13363-13383.

124 Weissmann C: Molecular biology of prion diseases. Trends Cell Biol 1994;4:10-14.

125 Horwich AL, Weissman JS: Deadly conformations - protein misfolding in prion disease. Cell 1997;89:499-510.

126 Lindquist S: Mad cows meet psi-chotic yeast: the expansion of the prion hypothesis. Cell 1997;89:495-498.

127 Prusiner SB, Groth D, Serban A, Koehler R, Foster D, Torchia M, Burton D, Yang SL, DeArmond SJ: Ablation of the prion protein $(\mathrm{PrP})$ gene in mice prevents scrapie and facilitates production of anti-PrP antibodies. Proc Natl Acad Sci USA 1993;90:1060810612.

128 Sailer A, Bueler H, Fischer M, Aguzzi A, Weissmann C: No propagation of prions in mice devoid of PrP. Cell 1994;77:967-968.

129 Steele AD, Emsley JG, Ozdinler PH, Lindquist S, Macklis JD: Prion protein $\left(\mathrm{PrP}^{\mathrm{c}}\right)$ positively regulates neural precursor proliferation during developmental and adult mammalian neurogenesis. Proc Natl Acad Sci USA 2006;103:3416-3421. 
130 Zhang CC, Steele AD, Lindquist S, Lodish HF: Prion protein is expressed on longterm repopulating hematopoietic stem cells and is important for their self-renewal. Proc Natl Acad Sci USA 2006;103:21842189.

131 Ma J, Lindquist S: De novo generation of a $\mathrm{PrP}^{\mathrm{Sc}}$-like conformation in living cells. Nat Cell Biol 1999;1:358-361.

132 Li A, Harris DA: Mammalian prion protein suppresses Bax-induced cell death in yeast. J Biol Chem 2005;280:17430-17434.

133 Lin MT, Beal MF: Mitochondrial dysfunction and oxidative stress in neurodegenerative diseases. Nature 2006;443:787-795.

134 Reverter-Branchat G, Cabiscol E, Tamarit J, Ros J: Oxidative damage to specific proteins in replicative and chronological-aged Saccharomyces cerevisiae: common targets and prevention by calorie restriction. J Biol Chem 2004;279:31983-31989.
135 Lee HC, Wei YH: Oxidative stress, mitochondrial DNA mutation, and apoptosis in aging. Exp Biol Med (Maywood) 2007;232: 592-606.

136 Lee HC, Wei YH: Mitochondrial alterations, cellular response to oxidative stress and defective degradation of proteins in aging. Biogerontology 2001;2:231-244.

137 Chen Q, Ding Q, Keller JN: The stationary phase model of aging in yeast for the study of oxidative stress and age-related neurodegeneration. Biogerontology 2005;6:1-13.

138 Kaeberlein M, McVey M, Guarente L: Using yeast to discover the fountain of youth. Sci Aging Knowledge Environ 2001;2001:pe1.
139 McMurray MA, Gottschling DE: Aging and genetic instability in yeast. Curr Opin Microbiol 2004;7:673-679.

140 Chen Q, Thorpe J, Keller JN: $\alpha$-Synuclein alters proteasome function, protein synthesis, and stationary phase viability. J Biol Chem 2005;280:30009-30017.

141 Outeiro TF, Kontopoulos E, Altmann S, Kufareva I, Strathearn KE, Amore AM, Volk CB, Maxwell MM, Rochet JC, McLean PJ, Young AB, Abagyan R, Feany MB, Hyman BT, Kazantsev A: Sirtuin 2 inhibitors rescue $\alpha$-synuclein-mediated toxicity in models of Parkinson's disease. Science 2007;317:516-519.

142 Bagriantsev S, Liebman S: Modulation of $\mathrm{A} \beta_{42}$ low-n oligomerization using a novel yeast reporter system. BMC Biol 2006;4: 32 